\title{
PRODUCTION AND CHARACTERIZATION OF BACTERIAL CELLULOSE FROM KOMAGATAEIBACTER XYLINUS ISOLATED FROM HOME-MADE TURKISH WINE VINEGAR
}

\author{
BURAK TOP, ${ }^{*}$ ERDAL UGUZDOGAN, ${ }^{* *}$ NAZIME MERCAN DOGAN, ${ }^{*}$ SEVKI ARSLAN, ${ }^{*}$ \\ NAIME NUR BOZBEYOGLU ${ }^{* * * *}$ and BUKET KABALAY* \\ "Department of Biology, Faculty of Arts and Science, Pamukkale University, 20070, Denizli, Turkey \\ ${ }^{* *}$ Department of Chemical Engineering, Faculty of Engineering, Pamukkale University, \\ 20070, Denizli, Turkey \\ *** Plant and Animal Production Department, Tavas Vocational High School, 20500, Denizli, Turkey \\ \Corresponding author: Naime Nur Bozbeyoglu,nbozbeyoglu@pau.edu.tr
}

Received February 23, 2021

In this research, bacterial cellulose (BC) was produced from Komagataeibacter xylinus S4 isolated from home-made wine vinegar (Denizli-Çal) and characterized through morphological and biochemical analyses. K. xylinus was identified by $16 \mathrm{~S}$ rDNA sequence analysis. The wet $(51.8-52.8 \mathrm{~g})$ and dry (0.43-0.735 g) weights of the produced BC were measured. The morphology of cellulose pellicles was examined by scanning electron microscopy (SEM) and a dense nanofiber network was observed. TGA analysis showed that the weight loss in the dehydration step in the BC samples occurred between $50{ }^{\circ} \mathrm{C}$ and $150{ }^{\circ} \mathrm{C}$, while the decomposition step took place between $215{ }^{\circ} \mathrm{C}$ and $228{ }^{\circ} \mathrm{C}$. Also, the cytotoxic effect, moisture content, water retention capacity and swelling behavior of $\mathrm{BC}$ were evaluated. In vitro assays demonstrated that $\mathrm{BC}$ had no significant cytotoxic effect. It was found that $\mathrm{BC}$ had antibacterial and antibiofilm potential (antibacterial effect>antibiofilm effect). All the results clearly showed that the produced BC can be considered as a safe material for different purposes, such as wound dressings.

Keywords: Komagataeibacter xylinus, bacterial cellulose, antibiofilm, cytotoxic activity, SEM, FTIR, TGA

\section{INTRODUCTION}

Microorganisms secrete a wide range of polymers, which have potential for use in different areas of the industry. Due to their complex physical and chemical structure, as well as biological properties, these biopolymers have economic and ecological value. Cellulose is one of the bacterial products and the most common biopolymer on earth. Bacterial cellulose is an extracellular polymer, which is the first product of cell metabolism and acts as a preservative. On the other hand, plant cellulose acts as a component of the cell. Plants are the largest source of cellulose in the world, but the world's resources are limited. Therefore, using microorganisms as an alternative to plants for cellulose production is important.

Bacterial cellulose (BC) is an exopolysaccharide produced by various bacteria, such as Acetobacter, Gluconacetobacter, Agrobacterium, Rhizobium, Cyanobacteria and
Salmonella. ${ }^{1-6}$ In recent years, there has been an increasing interest in bacterial cellulose as an important alternative to plant cellulose, due to its physical and chemical properties. $\mathrm{BC}$ has a high degree of purity and polymerization. In addition, its crystallization index is higher than that of plant cellulose. Moreover, its high tensile strength and high water holding capacity also provide potential for use in the paper and food industries. Moreover, it has potential applications in various industries, such as nano-paper, textiles, medicine, food, tissue engineering and nanotechnology. ${ }^{7-12}$

In large-scale $\mathrm{BC}$ production, the cost effectiveness is mainly dependent on the modification of known strains, finding novel producer strains or improving the $\mathrm{BC}$ production conditions. Therefore, the cellulose production conditions of bacteria must be optimized or new bacteria that can produce high amounts of cellulose should be screened. In the literature, 
many researchers have investigated the effects of novel isolated strains, different media, carbon and nitrogen sources, culture conditions, static and agitated incubation on the production of bacterial cellulose. ${ }^{2,13-17}$

In the present study, we aimed to determine the ability of $\mathrm{BC}$ production of a local isolate Komagataeibacter xylinus S4 strain in HSmodified with various carbon sources, such as glucose, mannitol, sucrose, arabinose and lactose. Also, the obtained BC was characterized by FTIR, SEM and thermal analysis, as well as in terms of its water holding capacity, antimicrobial and cytotoxic activities.

\section{EXPERIMENTAL}

\section{Strain isolation of and identification}

The strain S4 was isolated from home-made Turkish vinegar (Denizli-Çal, Turkey). First, the BC membrane was washed with saline water containing PBS. After that, for isolation and in all manipulations, Hestrin-Schramm (HS) medium was used (g/L): glucose 20; disodium hydrogen phosphate, 2.7; citric acid, 1.15; peptone 5; yeast extract, 5; agar, $14 .^{18}$ The DNA of the isolated S4 strain was isolated by using the GeneJET Genomic DNA Purification Kit (Thermo Scientific) according to the manufacturer's procedure. The 16S rDNA gene was amplified by using the primers 27F (AGAGTTTGATCCTGGCTCAG), 529F (GTGCCAGCMGCCGCGG) and 1491R (ACGGCTACCTTGTTACGACTT) on a Thermalcycler (QLS Optimus 96G). The polymerase chain reaction (PCR) mixtures consisted of $15 \mu \mathrm{l} 2 \mathrm{X}$ Amp Master Taq (GeneAll), $2 \mu \mathrm{l}$ for reverse and forward primers, $5 \mu \mathrm{l}$ DNA template and $6 \mu \mathrm{l}$ PCR grade $\mathrm{H}_{2} \mathrm{O}$. The PCR products were checked by using $1 \%$ agarose gel electrophoresis. The PCR products were isolated from the gel and sequenced. The bacterial strain was identified by $16 \mathrm{~S}$ rDNA analysis (Triogen Biotechnology, Istanbul, Turkey).

\section{Biochemical and physiological tests}

For the phenotypic and chemotaxonomic characterization of the S4 strain, morphological, physiological and biochemical tests were carried out (Table 1). The acetic acid production of the S4 strain was confirmed by Carr medium (g/L: yeast extract, 30 ; Bromocresol Purple, 0.022; agar, 20; ethyl alcohol 20 $\mathrm{mL} / \mathrm{L})$ and Frateur medium (g/L: glucose, 0.5; peptone, 3; yeast extract, 5; calcium carbonate, 15; agar, 12; ethyl alcohol, $15 \mathrm{~mL} / \mathrm{L}) .{ }^{19}$ In order to observe the cellulose production activity of the S4 strain on the solid medium, a fluorescent brightener 28 (FB28, Calcofluor White), with non-specific fluorochrome binding to cellulose, was added at $0.2 \mathrm{~g} / \mathrm{L}$ in $\mathrm{HS}$ medium and the colonies on the surface of the agar medium were examined under UV. ${ }^{20}$
Bacterial cellulose production, culture conditions and bleaching of cellulose

The S4 strain was incubated at $30{ }^{\circ} \mathrm{C}$ for 4-14 days in HS medium. At the end of the incubation period, the $\mathrm{BC}$ formed on the surface of the medium was gently taken and kept in $0.1 \mathrm{M} \mathrm{NaOH}$ at $80{ }^{\circ} \mathrm{C}$ for $1 \mathrm{~h}$. After the $\mathrm{BC}$ was washed with $\mathrm{dH}_{2} \mathrm{O}$ until the $\mathrm{BC}$ reached neutral $\mathrm{pH},{ }^{21}$ it was lyophilized and stored at $-20{ }^{\circ} \mathrm{C}$ for analyses.

\section{Water absorption}

The water absorption capacity of the BC sample was determined by the method described by Lin et al. ${ }^{22}$ with slight modifications. Briefly, lyophilized and dried BC membranes were cut into small pieces $(4 \times 4$ $\mathrm{cm}$ ) and were weighed (labelled as $\mathrm{W}_{\mathrm{dry}}$ ). The material was merged into water and incubated at $25{ }^{\circ} \mathrm{C}$ for $24 \mathrm{~h}$. Specimens were removed at certain intervals and then weighed $\left(\mathrm{W}_{\text {wet }}\right)$ after removing excess water. The water absorption was determined by calculating the increase in weight percent by the formula:

Water absorption $(\%)=[$ (Wet weight of BC - Dry weight of BC)/Dry weight of BC] 100

Similarly, the moisture content of bacterial cellulose was calculated by using the following formula. Two replications were performed for this experiment.

Moisture content $(\%)=\left[\left(\mathrm{W}_{\text {wet }}-\mathrm{W}_{\mathrm{dry}}\right) / \mathrm{W}_{\text {wet }}\right] \times 100$

\section{Water retention}

The water retention capacity of bacterial cellulose was determined according to the method of Lin et al. ${ }^{22}$ The lyophilized and dried bacterial cellulose membranes were weighed to determine their initial dry weight $\left(\mathrm{W}_{\mathrm{dry}}\right)$. Then, these materials were soaked into deionized water for $24 \mathrm{~h}$. After this duration, the membranes were taken out from water and excess water was removed by using filter paper. The weights of the samples placed on an open plate were measured at certain time periods $\left(\mathrm{W}_{\text {wet }}\right)$. The percent water retention of $\mathrm{BC}$ was calculated by using the following formula. Two replications were performed for this experiment.

Water retention $(\%)=\left[\left(\mathrm{W}_{\text {wet }}-\mathrm{W}_{\text {dry }}\right) / \mathrm{W}_{\text {dry }}\right] \times 100$

\section{Cell culture and cytotoxicity assay}

Human embryonic kidney 293 cells line (HEK293) were obtained from the European Collection of Cell Cultures (ECACC, UK). Cells were cultured in DMEM, including $10 \%$ FBS and $1 \%$ penicillin/streptomycin mixture, in a humidified atmosphere $\left(95 \%\right.$ air with $5 \% \mathrm{CO}_{2}$ ) at $37{ }^{\circ} \mathrm{C}$. HEK293 cells were grown in 96-well plates at a density of $1 \times 10^{3}$ cells/mL culture medium. After $24 \mathrm{~h}$ of growth, the medium was removed, and cells were treated with extracted bacterial cellulose. The extraction was performed as described in Lin et $a .^{22}$ with slight 
modifications. Briefly, $2 \times 2 \mathrm{~cm}$ cut bacterial cellulose was extracted at $37{ }^{\circ} \mathrm{C}$ for $24 \mathrm{~h}$ in culture media in a shaker. After $24 \mathrm{~h}$, the medium was removed and filtered. An equal amount of medium without extract was added to untreated cells (control). Cellulose treated and control cells were incubated for $48 \mathrm{~h}$. Following incubation, medium containing floating cells were removed, and attached cells were treated with crystal violet $[0.5 \%(\mathrm{w} / \mathrm{v})$ in $10 \%$ ethyl alcohol]. The dye absorbed by live cells was solubilized with sodium citrate $(0.1 \mathrm{M}$ in $50 \%$ ethyl alcohol). Colour intensity was determined at $630 \mathrm{~nm}$. Three replicated wells were used for each experimental condition. Viability was expressed as a percentage of the control.

\section{Antibiofilm activity}

The antibiofilm activity of cellulose was determined according Jain et al. ${ }^{23}$ TSB medium, $S$. aureus ATCC 29213 and cellulose discs (2x2 mm) were added in 96-well microplates. For biofilm production, the plates were incubated at $37^{\circ} \mathrm{C}$ for $24 \mathrm{~h}$. At the end of the period, the samples were washed three times with sterile PBS (phosphate buffer saline) and dried. The wells were stained for 15 minutes by $0.1 \%$ crystal violet and washed with PBS. Finally, 33\% glacial acetic acid was added to each well and the absorbance at $630 \mathrm{~nm}$ wavelength was read by a Microplate Reader (Optic Ivymen System 2100-C). The biofilm inhibition of $\mathrm{BC}$ was calculated by using the following formula:

Biofilm inhibition $(\%)=\left[\left(\mathrm{OD}_{\text {final }^{-}} \mathrm{OD}_{\text {initial }}\right) / \mathrm{OD}_{\text {initial }}\right]$ $\mathrm{x} 100$

\section{Antibacterial activity}

S. aureus ATCC 33862, E. coli ATCC 25922, E. coli $\mathrm{O}: 157 \mathrm{H}:$ 7, B. cereus RSKK 863, B. pumilis NRRL-BD-142 and E. faecalis ATCC 19433 were used. The bacteria were obtained from Pamukkale University, Department of Biology, Bacteriology Laboratory, Bacterial Culture Collection. Firstly, the cells were incubated at $37{ }^{\circ} \mathrm{C}$ for $6-8 \mathrm{~h}$ in Muller Hinton Broth (MHB). After that, they were centrifuged at $3000 \mathrm{rpm}$ for $10 \mathrm{~min}$. The pellet was washed 2-3 times with PBS and suspended with PBS according to McFarland 0.5. Sterile cellulose discs $(7.5 \times 7.5 \mathrm{~mm})$ were applied in two different ways. First, the cellulose was immersed in PBS with bacteria and removed instantly. Second, the cellulose discs were added in PBS with bacteria and incubated at $37^{\circ} \mathrm{C}$ for $24 \mathrm{~h}$. The discs were placed in $1 \mathrm{~mL}$ of sterile PBS and vortexed. Finally, $1 \mathrm{~mL}$ of this solution was used for serial dilutions and inoculated on solid agar. The Petri dishes were incubated at $37{ }^{\circ} \mathrm{C}$ for $24 \mathrm{~h}$. At the end of the period, the colonies were counted as $\mathrm{CFU} / \mathrm{mL}^{24}$

\section{Fourier transform infrared (FTIR) spectroscopy}

The FTIR spectra of the samples were recorded using a Bruker Vertex 70 V FTIR spectrometer (Germany), with an ATR (attenuated total reflectance) accessory unit, in the region from 400 to $4000 \mathrm{~cm}^{-1}$ at the ambient temperature.

\section{Thermogravimetric analysis}

Thermal decomposition behaviors of the samples were carried out with Perkin-Elmer Diamond thermogravimetric analysis (TG/DTG) device. About 5 $\mathrm{mg}$ of a sample was placed in a ceramic pan and heated at $10{ }^{\circ} \mathrm{C} / \mathrm{min}$ from $50{ }^{\circ} \mathrm{C}$ to $600{ }^{\circ} \mathrm{C}$ under $\mathrm{N}_{2}$ atmosphere $(200 \mathrm{~mL} / \mathrm{min})$. Differential scanning calorimetry (DSC) analyses of the samples were performed using a Perkin-Elmer Pyris 6 DSC instrument. The sample was put in an aluminum pan and heated from $0{ }^{\circ} \mathrm{C}$ to $400{ }^{\circ} \mathrm{C}$ under $\mathrm{N}_{2}$ atmosphere (20 $\mathrm{mL} / \mathrm{min})$.

\section{Scanning electron microscopy}

Electron microscopy analysis was carried out at PAU-ILTAM (Denizli) and Akdeniz University, Medical Faculty (Antalya).

\section{Statistical analysis}

Statistical analyses were performed by using the Minitab statistical software package and the SPSS statistical package for Windows. All the results were expressed as means with their Standard Error of Means (SEM). A comparison between the two groups was performed by Student's t-test and $\mathrm{p}<0.05$ was chosen as the level of significance.

\section{RESULTS AND DISCUSSION}

Screening and selection of new isolates for efficient production of bacterial cellulose is one of the most important goals in producing large amounts of that material. For this reason, various microorganisms have been isolated from different sources by many researchers and their cellulose production capacity was investigated. Although numerous bacteria, such as Rhizobium, Agrobacterium, Acetobacter, Salmonella and Alcaligenes can synthesize cellulose, Komagataeibacter xylinum are the most used bacteria in cellulose production. ${ }^{25}$ In other words, it may be a model cellulose-producer. Therefore, we firstly isolated a local isolate S4 from homemade grape vinegar in the current study. Some biochemical test results of the isolates are given in Table 1. It showed negative rods for gram reaction, aerobic, catalase and cellulose production positive. The isolate was inoculated on Carr and Freuter media for determining acetic acid production. At the end of the incubation, the color of Carr medium turned yellow due to the acid produced by the S4 strain and it was confirmed that it was an acetic acid bacterium (Fig. 1A and 1B). Transparent zones were 
observed around the colonies on Freuter medium containing $\mathrm{CaCO}_{3}$ and acetic acid production was confirmed (Fig. 1C). In addition, the S4 strain was cultivated on Calcofluor agar and observed under UV light. The cellulose positive colonies glowed under UV light and separated from those that did not produce cellulose because the Flourescent brightener 28 in Calcofluor agar binds with cellulose fibers (Fig. 1D). Moreover, the 16S rDNA analysis showed that the strain S4 was $100 \%$ identical to Komagataeibacter xylinus (GenBank: KX216690.1 and KX216693.1).
The production of $\mathrm{BC}, \quad \mathrm{a}$ recognized multifunctional biomaterial, depends on the type of culture, oxygen, temperature, $\mathrm{pH}$ and culture conditions. The BC from $K$. xylinum $\mathrm{S} 4$ was produced in standard HS medium. The BC production and appearance are presented in Figure 2. The weight of wet $\mathrm{BC}$ was 51.8-52.8 g, while its dry weight was estimated as $0.43-0.735$ $\mathrm{g}$. The only difference was observed regarding the dry weight of $\mathrm{BC}$ after 14 days of incubation. There was a slightly higher than $100 \%$ increase in dry weight due to incubation (Table 2).

Table 1

Identification tests used for $K$. xylinus $\mathrm{S} 4$

\begin{tabular}{lc}
\hline K. xylinus S4 & + \\
\hline Catalase & + \\
Production of cellulose & + \\
Growth on medium containing $\mathrm{CaCO}_{3}$ & + \\
Growth at $\mathrm{pH}=2$ & + \\
Acid formation from glucose & + \\
Acid formation from sucrose & + \\
Acid formation from fructose & + \\
Acid formation from lactose & + \\
Acid formation from maltose & - \\
Oxidase & - \\
Indole production & - \\
Methyl Red & - \\
Voges-Proskauer & - \\
Utilization of sodium citrate & - \\
$\mathrm{H}_{2} \mathrm{~S}$ formation & - \\
Urea utilization & - \\
Gelatin liquefaction & - \\
\hline
\end{tabular}

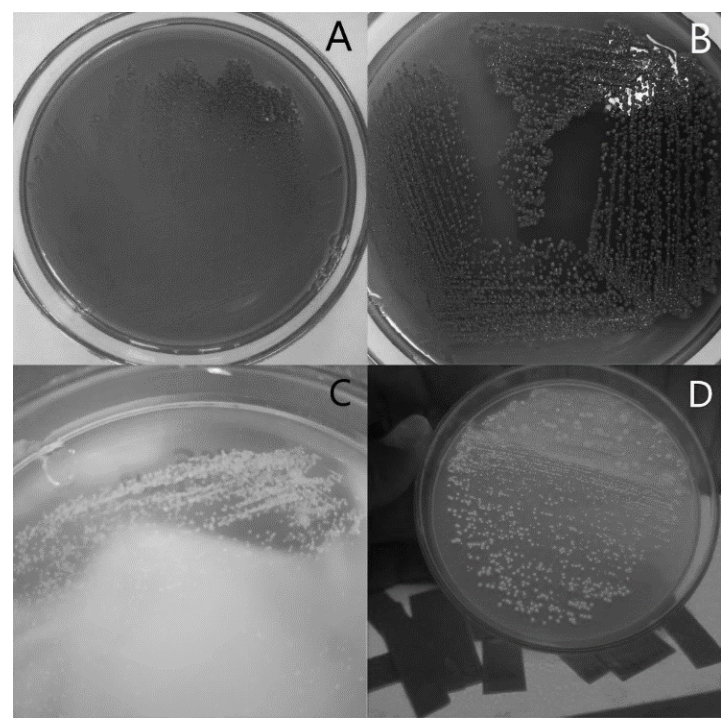

Figure 1: Carr (A and B), Frauter (C) and Calcofluor Agar (D) media used for isolation 
Bacterial cellulose

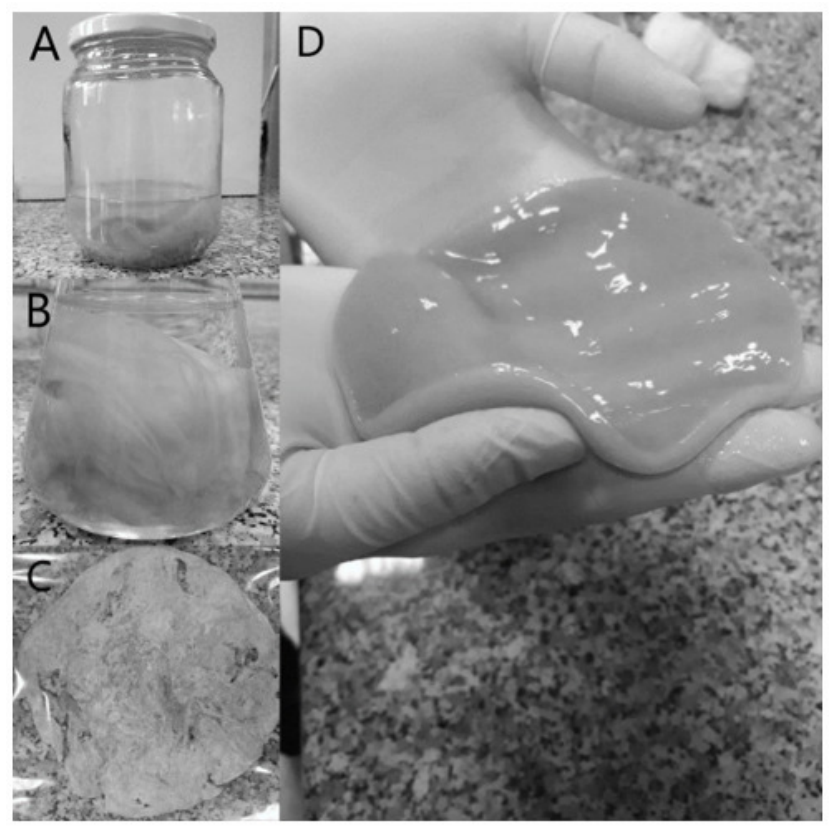

Figure 2: Images of bacterial cellulose production; A: pellicle in main source, B: bleaching of cellulose, $\mathrm{C}$ and D: wet and lyophilized cellulose

Table 2

Production of cellulose by Komagataeibacter xylinus S4 (g/L)

\begin{tabular}{lcc}
\hline Incubation & Dry weight & Wet weight \\
\hline 5 days & $0.6320 \pm 0.0000$ & $51.8000 \pm 0.0000$ \\
7 days & $0.5325 \pm 0.0205$ & $52.0520 \pm 1.5000$ \\
10 days & $0.4300 \pm 0.0100$ & $40.0460 \pm 0.9180$ \\
14 days & $0.7350 \pm 0.0850$ & $52.8035 \pm 2.6745$ \\
\hline
\end{tabular}

\section{Antibacterial activity}

Bacterial cellulose has many uses (e.g., food, cosmetics, medicine, biomedical, etc.). The most important reason for having such a wide area of application is undoubtedly its antimicrobial effect. ${ }^{26-28}$ Therefore, the antibacterial effect of $\mathrm{BC}$ was investigated in our study. As seen in Table 3, the BC exhibited a strong effect in the presence of both momentary contact and $24 \mathrm{~h}$ contact. The antibacterial effect after $24 \mathrm{~h}$ contact was more efficient than after momentary contact. Figure 3 shows observations of the antibacterial effect of BC.

Numerous studies have been reported on the antibacterial effect of BC in the literature. In most of these studies, bacterial cellulose was treated with various antimicrobial agents. For example, BC obtained from A. xylinum was coated with chitosan (BC-Ch) and the antibacterial effect of pure $\mathrm{BC}$ and $\mathrm{BC}-\mathrm{Ch}$ was tested against $S$. aureus and E. coli. While untreated $\mathrm{BC}$ and $\mathrm{BC}-\mathrm{Ch}$ inhibited $S$. aureus growth with $30.4 \%$ and $99.9 \%$, respectively; $E$. coli growth was inhibited by $49.2 \%$ with untreated $\mathrm{BC}$ and $99.9 \%$ with BC$\mathrm{Ch}$, respectively. ${ }^{22}$ In another study, lysozyme was immobilized onto bacterial cellulose nanofibers (BCNF) and the antimicrobial activity of the lysozyme against Staphylococcus aureus, Escherichia coli, Listeria monocytogenes, Yersinia entrocolitica, Aspergillus niger and Saccharomyces cereviseae was increased after immobilization. ${ }^{29}$ According to Adepu and Khandelwal, ${ }^{30}$ bacterial cellulose modified by silver (AgBC) exhibited $99.9 \%$ antimicrobial activity sustained for $72 \mathrm{~h}$ against a mixed culture of both bacteria and fungi. 
Table 3

Antibacterial activity results of bacterial cellulose (\%)

\begin{tabular}{lcc}
\hline Bacteria & Momentary contact & $24 \mathrm{~h}$ \\
\hline S. aureus ATCC 33862 & 89.08 & 91.56 \\
E. coli ATCC 25922 & 98.86 & 99.99 \\
E. coli O: 157 H:7 & 99.79 & 100.00 \\
B. cereus RSKK 863 & 99.57 & 99.99 \\
B. pumilis NRRL-BD-142 & 99.26 & 99.99 \\
E. faecalis ATCC 19433 & 97.87 & 95.83 \\
\hline
\end{tabular}

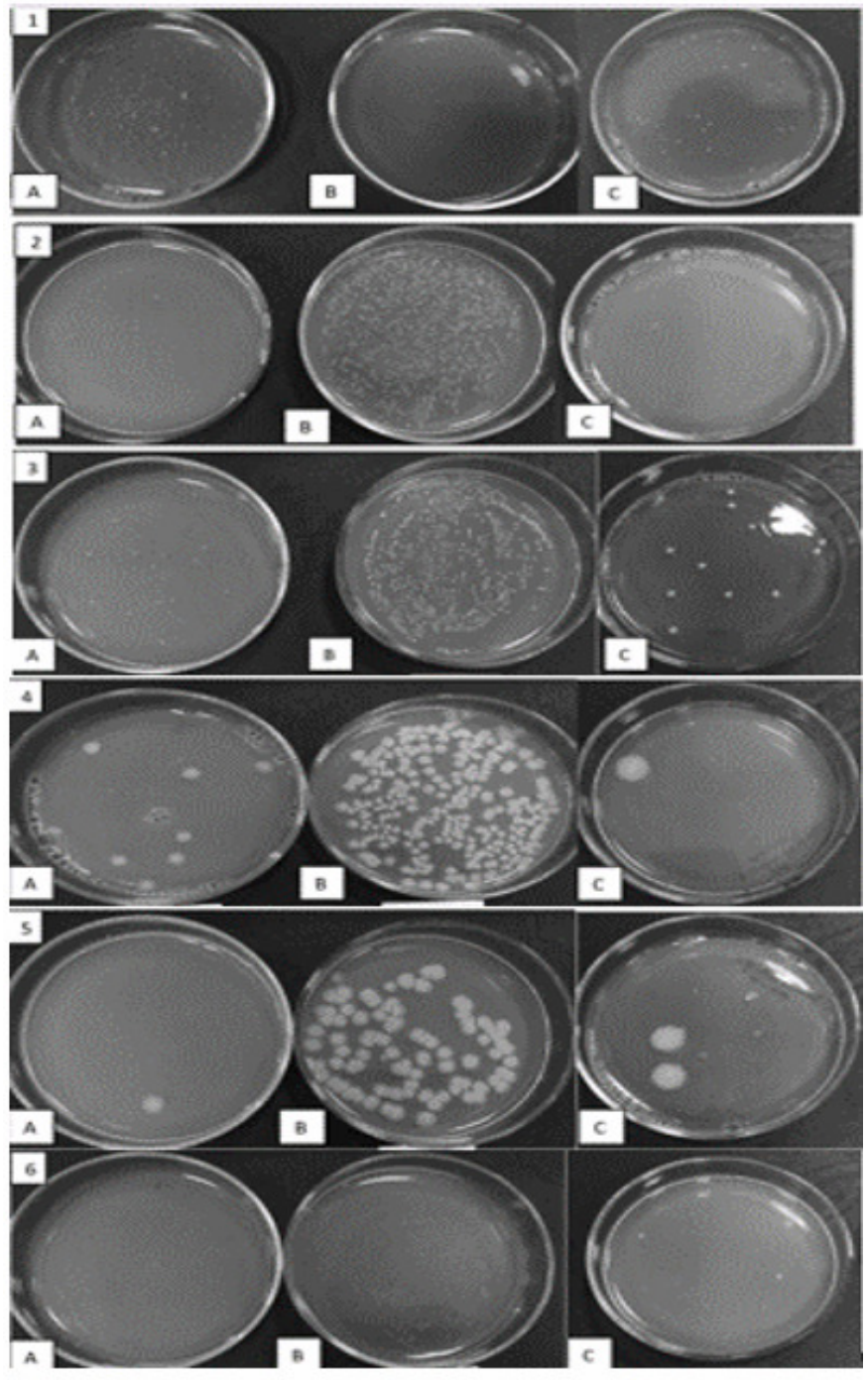

Figure 3: Antibacterial efficacy of bacterial cellulose against S. aureus ATCC 33862 (1A, control; 1B, after momentary contact and 1C, $24 \mathrm{~h}$ contact with BC), E. coli O:157 H:7 (2A and 2C after momentary contact and $24 \mathrm{~h}$ contact with BC, respectively, 2B, control), E. coli ATCC 25922 (3B, control, 3A and 3C, after momentary and 24 h contact with BC), B. cereus RSKK 863 (4B, control, 4A and 4C, after momentary and 24 h contact with BC), B. pumilis NRRL-BD142 (5B, control, 5A and 5C, after momentary and $24 \mathrm{~h}$ contact with BC), E. faecalis ATCC 19433 (6B, control, 6A and $6 \mathrm{C}$, after momentary and $24 \mathrm{~h}$ contact with $\mathrm{BC})$ 
Contrary to these results, $\mathrm{BC}$ purified from our local isolate exhibited high antibacterial activity, even without being coated with any substance. In other words, our pure BC was clearly more effective than modified $\mathrm{BC}$ used in the literature. According to the antibacterial screening test, it was shown that the activity of BC was good against all the used organisms (Table 3). However, S. aureus ATCC 33862 and E. faecalis ATCC 19433 were less resistant than E. coli ATCC 25922 , E. coli O:157 H:7, B. cereus RSKK 863, B. pumilis NRRL-BD 142. This result means more specific interaction of $\mathrm{BC}$ with these bacteria. Moreover, the cell walls composition and structure of gram-positive and gram-negative bacteria are also different. That is why, the attachment of BC fibers may be strain specific.

\section{Biofilm inhibition and eradication by BC}

Many bacterial infections, for example, chronic wounds, are associated with biofilms. Combating with antibiotic applications of biofilm-associated infections is more difficult because biofilm increases antibiotics resistance of pathogens. Therefore, non-antibiotics strategies are being developed to eradicate biofilm infections. Bacterial cellulose as an antibiofilm composite can be one of these alternatives. ${ }^{31,32}$ In our study, the antibiofilm activity of BC was detected by using the crystal violet method. $S$. aureus ATCC 33862, S. aureus ATCC 29213, E. coli ATCC 25922, E. coli O:157H:7, B. cereus RSKK 863, B. pumilis NRRL-BD-142 and $E$. faecalis ATCC 19433 were used as indicator

Table 4

Antibiofilm effect of bacterial cellulose (\%)

\begin{tabular}{lc}
\hline S. aureus ATCC 29213 & \\
\hline Biofilm inhibition & $22.050 \pm 6.675$ \\
Biofilm eradication & $9.495 \pm 0.808$ \\
\hline
\end{tabular}

\section{Cytotoxicity of bacterial cellulose}

The cytotoxic effect of $\mathrm{BC}$ was determined as described in the experimental part by using HEK293 cell line. As shown in Figure 4, the viability of cells decreased slightly because of $\mathrm{BC}$ treatment. However, this decrease was not found to be statistically significant. Quite similar results were observed in different studies. ${ }^{22,33}$ Although a $15 \%$ decrease was observed in the $\mathrm{BC}$ obtained from Acetobacter xylinum, ${ }^{22}$ our isolated BC caused an $8 \%$ decrease in cell viability. It is well established that a small decrease in viability can pathogens. According to our results tabulated in Table 4, the BC inhibited only biofilms of $S$. aureus ATCC 29213. The antimicrobial and antibiofilm activity of $\mathrm{BC}$ modified with various antimicrobial substances were mostly screened. The rates of biofilm inhibition and eradication were of $22.05 \%$ and $9.495 \%$, respectively. According to the literature information, there is only one article investigating the antibiofilm effect of cellulose. For example, Zhang et al. ${ }^{32}$ indicated that the BC-modified-tannic acid composites significantly reduced biofilm formation of $S$. aureus and $P$. aeruginosa after 24 $\mathrm{h}$ incubation by $\sim 80 \%$ and $\sim 87 \%$, respectively. In the study by Krasowski et al., ${ }^{31}$ bacterial cellulose was treated with oral antiseptics and a very high antibiofilm effect was found. Contrary to Zhang et al. ${ }^{32}$ and Krasowski et al., ${ }^{31}$ we tested the antibiofilm efficacy of pure BC and because of this, the antibiofilm effect was lower than the results of Zhang and co-authors, and Krasowski and co-authors. Indeed, most bacterial exopolysaccharides are not biofilm specific. SEM images of bacterial cellulose indicated cellulose fibers and pores on the surface. We considered that the antibacterial and antibiofilm effect of pure cellulose might be due to its fibrils and porous structure that attach to bacteria. This result proved the potential of our $\mathrm{BC}$ in biofilm inhibition, but pure $\mathrm{BC}$ must be modified to be used in many more applications. be considered as safe in the application of bacterial cellulose for different purposes. In addition to the cytotoxic effects, the moisture content, water retention capacity and swelling behavior of $\mathrm{BC}$ were evaluated in this study. As can be seen in Figure 5, the isolated BC has a 55.3-fold swelling ratio, compared to its dry weight, after $24 \mathrm{~h}$. Similarly, the moisture content was found to be of $98.2 \%$ (Fig. 6). Water retention was evaluated for $24 \mathrm{~h}$ in this study. Most of the water was removed from BC after 24 h (Fig. 7). 


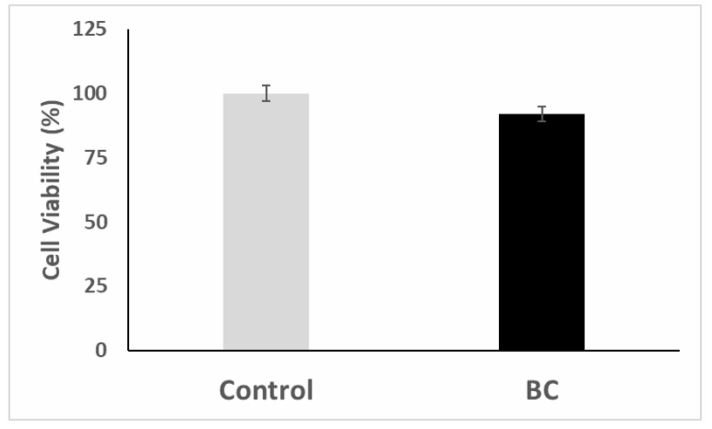

Figure 4: Cytotoxic effect of bacterial cellulose (BC) on HEK293 cells after $48 \mathrm{~h}$ incubation. Results are mean \pm SD values for three independent experiments

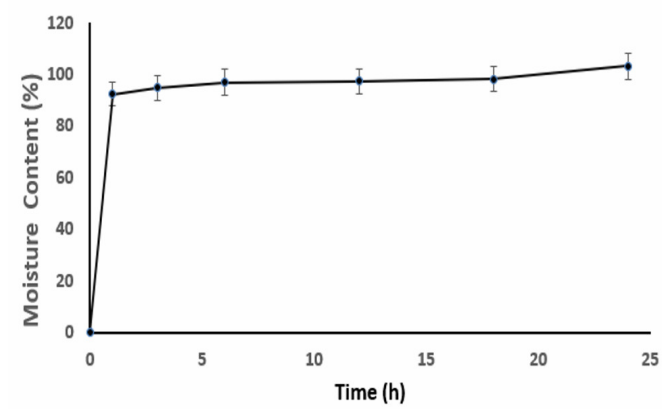

Figure 6: Moisture content of bacterial cellulose. Results are mean \pm SD values for three independent experiments

One of the possible applications of bacterial cellulose may be in wound healing. It is well known that many factors can have an influence in wound healing process, including age, sex, moisture, infection. ${ }^{34,35}$ To increase this physiological process, natural and synthetic materials have been examined for their usage potential as wound dressings. One of the materials that can be used for this purpose is cellulose. It is found extensively in plants and produced by bacteria as well. Although their chemical nature is the same, their microstructures are different. ${ }^{36}$ Our results showed that $\mathrm{BC}$ can maintain a moisture environment around the wound and can help the wound healing process. Isolated bacterial celluloses from different sources showed similar results, as described previously. ${ }^{22,37}$ All these results showed that $\mathrm{BC}$ may have potential in contributing to the wound healing process. Further experiments, such as in vivo animal tests, will be required to clarify the role of $\mathrm{BC}$ in wound healing.

\section{FTIR analysis}

Fourier transform infrared spectroscopy (FTIR) analysis provides important information

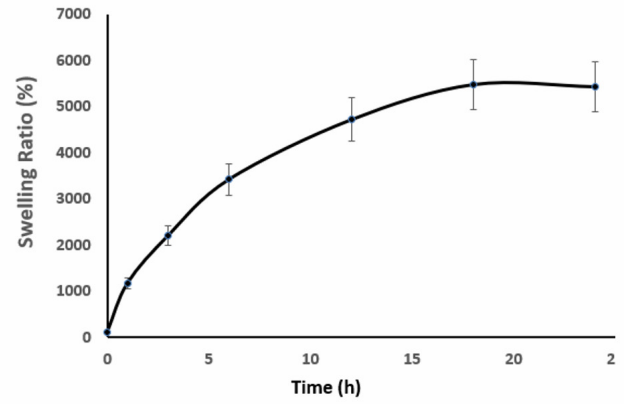

Figure 5: Swelling ratio of bacterial cellulose. Results are mean \pm SD values for three independent experiments

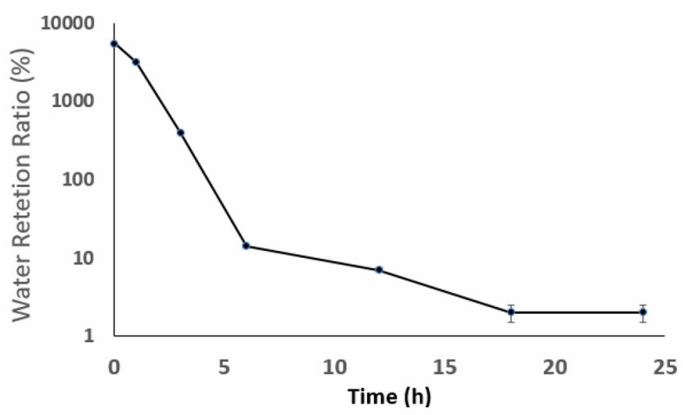

Figure 7: Water retention capacity of bacterial cellulose. Results are mean \pm SD values for three independent experiments

about the existence of functional groups in a molecule, polymer, or composite material. ${ }^{38-40}$ FTIR analysis was used to detect functional groups and the binding properties of these groups in the cellulose samples (Fig. 8). Stretching vibrations of the hydroxyl groups $(-\mathrm{OH})$ of the samples, due to hydrogen bonds formation, appeared as a broad absorption band around 3400$3300 \mathrm{~cm}^{-1}$. The absorption bands that appeared around $2950-2850 \mathrm{~cm}^{-1}$ are probably related to the $\mathrm{C}-\mathrm{H}$ asymmetric/symmetric stretching vibrations of methylene $\left(\mathrm{CH}_{2}\right)$ and methyl $\left(\mathrm{CH}_{3}\right)$ groups. The stretching vibration of the carbonyl $(\mathrm{C}=\mathrm{O})$ group of proteins and lipids can be easily recognized at $1727 \mathrm{~cm}^{-1}$. The peaks in the range of 1426 and $1315 \mathrm{~cm}^{-1}$ possibly belong to the bending vibrations of $\mathrm{CH}_{2}$ and $\mathrm{C}-\mathrm{H}$ groups of polysaccharides. The stretching vibration of the $\mathrm{C}-\mathrm{O}$ group was observed at $1159 \mathrm{~cm}^{-1}$. The absorption bands around $1000-1200 \mathrm{~cm}^{-1}$ are attributed to the existence of $\mathrm{C}-\mathrm{O}$ and $\mathrm{C}-\mathrm{O}-\mathrm{C}$ functional groups of the pyranose ring. The other vibration peaks observed for the commercial cellulose and main source material used in the study (BC) are assigned to $-\mathrm{C}-\mathrm{H}$ out-of-plane bending $\left(896 \mathrm{~cm}^{-1}\right)$, and $-\mathrm{OH}$ out-of-plane 
bending (666-619 $\left.\mathrm{cm}^{-1}\right)$. Both absorption bands are typical of the cellulose structure, with a few exceptions in the case of the main source (BC) spectra. The absorption band around $1640 \mathrm{~cm}^{-1}$, which exhibited higher peak intensity in the spectrum of the main source (BC), compared to that of commercial cellulose, is due to absorbed water. Moreover, the peak at $1552 \mathrm{~cm}^{-1}$, which corresponds to protein amide II absorption, disappeared in commercial cellulose. ${ }^{41}$ This is thought to be the result of insufficient purification applied to the main source. All the above characteristics of the FTIR spectra provide evidence of BC synthesis.

\section{Thermogravimetric analysis}

Thermogravimetric analyses (TGA) of the samples were accomplished in order to detect the thermal decomposition behavior of the samples during the thermochemical transformation. Since TGA results are dependent on many parameters, including geometries of samples, the amount of sample and heating rate, these parameters were kept the same during the analysis. The decrease in the mass of the samples was determined and the thermogravimetric (TGA) and differential thermal analysis (DTG) curves are given in Figures 9 and 10. In addition, some results obtained from the TGA and DTG curves while heating samples to $550{ }^{\circ} \mathrm{C}$, such as the initial temperature of decomposition, the end temperature of the decomposition, the maximum decomposition temperature and the carbonaceous residue after pyrolysis, are given in Table 5.
The thermal decomposition steps of the samples occur mainly due to the dehydration and depolymerization of the polymeric structures. ${ }^{42}$ As can be seen from the figures, the dehydration step occurs between $50{ }^{\circ} \mathrm{C}-145{ }^{\circ} \mathrm{C}$, due to the loss of absorbed water in the samples, which is consistent with previous reports. ${ }^{43-46} \mathrm{BC}$ mainly shows moderate thermal stability under the applied conditions and its decomposition occurs rapidly between $250{ }^{\circ} \mathrm{C}-350{ }^{\circ} \mathrm{C} .{ }^{47}$ The main decomposition step, with a higher percentage mass loss, occurred between 215 and $310{ }^{\circ} \mathrm{C}$ in the samples. It is observed that the second degradation step starts at temperatures between 215 and $228^{\circ} \mathrm{C}$, as can be seen from the figures given. In addition, the DTG curves obtained from the thermal analysis of the samples show that the maximum weight loss rate of this degradation is recorded between $272.72-287.46^{\circ} \mathrm{C}$ temperatures. The temperature values at which degradation ends in samples obtained with different carbon sources are between $288{ }^{\circ} \mathrm{C}$ and $326^{\circ} \mathrm{C}$, as shown in the table. These values are relatively low when compared with the literature results. ${ }^{45,46,48-50}$

Some structural parameters, such as the orientation, crystallinity and molecular weight of cellulose fibers, affect the thermal degradation behavior. ${ }^{46}$ Besides these structural parameters, reasons such as the cleaning procedure used in the purification of the samples, the method of preparing the samples for thermal analysis, the morphology of the samples, the sample size, etc., can affect the thermal degradation behavior. ${ }^{51}$

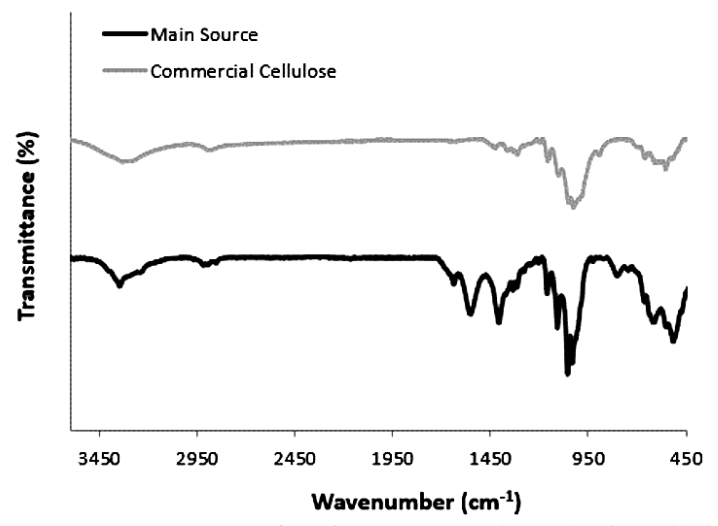

Figure 8: FTIR spectra of main source and synthetic cellulose 


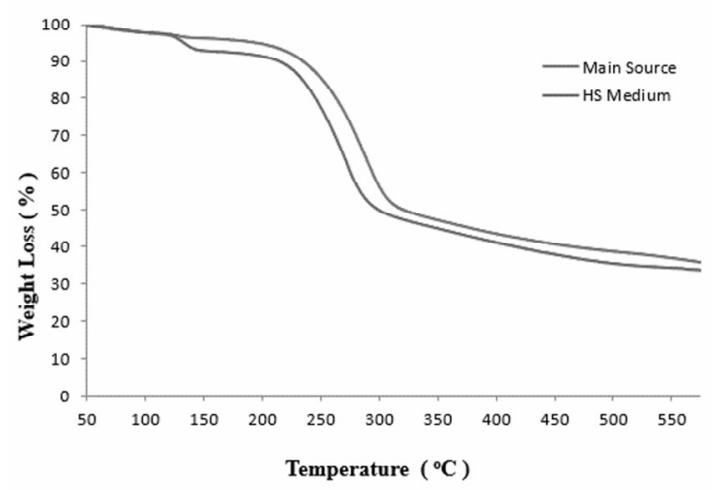

Figure 9: Thermogravimetric analysis curves of BC

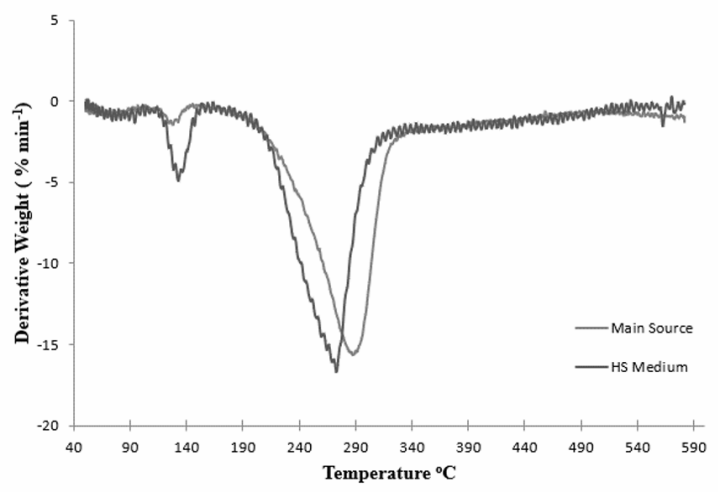

Figure 10: Differential thermal analysis curves of BC and main source

Table 5

Some results read from TGA-DTG curves of BC samples produced in HS medium with different carbon source of Komagataeibacter xylinus $\mathrm{S} 4$ bacteria

\begin{tabular}{lcccc}
\hline Carbon source & $\mathrm{T}_{\text {onset }}\left({ }^{\circ} \mathrm{C}\right)$ & $\mathrm{T}_{\text {offset }}\left({ }^{\circ} \mathrm{C}\right)$ & $\mathrm{T}_{\max }\left({ }^{\circ} \mathrm{C}\right)$ & Pyrolysis residue at $550{ }^{\circ} \mathrm{C}(\%)$ \\
\hline Main source & 214.49 & 325.84 & 287.46 & 36.8 \\
HS medium & 227.23 & 288.1 & 272.72 & 34.19 \\
\hline
\end{tabular}

According to the literature mentioned above, this relative deviation is thought to be mainly due to the method of purification of the samples, as it was observed that the degradation step of the samples obtained by changing the washing procedure applied in cleaning them in another part of the study was more compatible with the results found in the literature. The accuracy of this evaluation is supported by the high residual pyrolysis values recorded after the samples are heated to $550{ }^{\circ} \mathrm{C}$.

\section{SEM analysis}

Figure 11 presents the morphology of cellulose pellicles obtained from Komagataibacter xylinus
S4. Although the reticular structure of the cellulose pellicles in the main source and pure BC was similar, the fibril thickness was different. The fibrils of pure $\mathrm{BC}$ were thinner than those of the pellicles in the main source. Moreover, the main source was more compact in the background, and the fibril distribution was infrequent. The interfacial adhesion was very intense in BC. Jung et $a l^{52}$ reported that the $\mathrm{BC}$ samples had reticulated structure consisting of ultra-fine cellulose fibrils. Acetobacter xylinum cellulosic fibrils were similar to pure microcrystalline cellulose fibrils. ${ }^{53}$ Thus, the morphological structure of our cellulose was not different from that described in the literature.

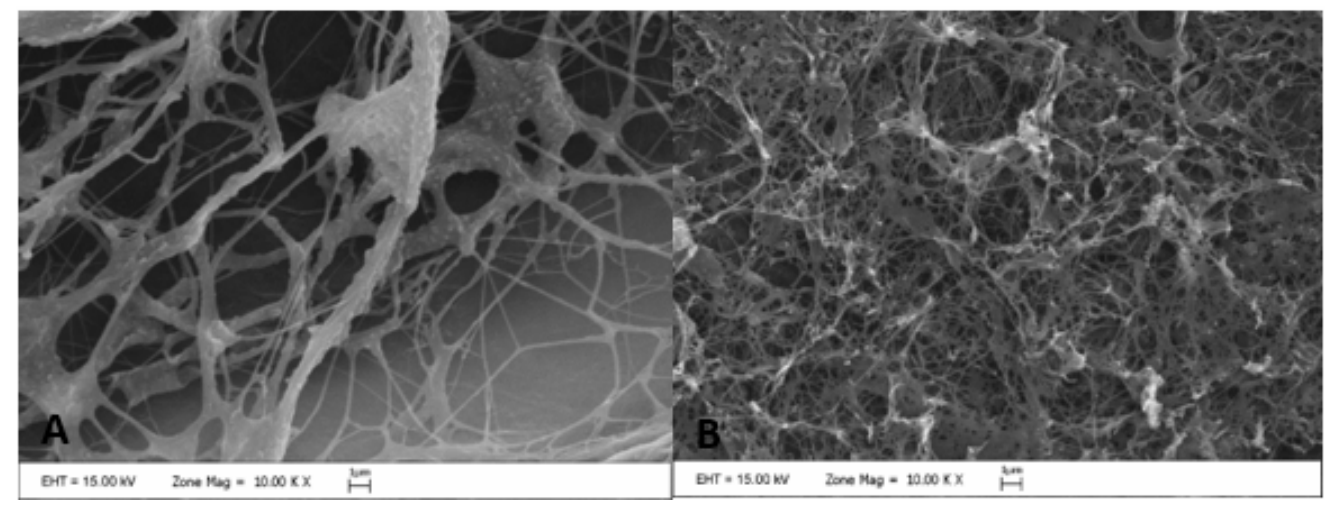

Figure 11: Images of BC from $K$. xylinus $\mathrm{S} 4$ (A - the main source from which strain $\mathrm{S} 4$ was isolated, and $\mathrm{B}-\mathrm{BC}$ obtained from HS medium) 


\section{CONCLUSION}

The antibacterial, antibiofilm and cytotoxic activity, as well as moisture content, water retention capacity and swelling behavior of BC produced by Komagataeibacter xylinus were studied for the first time in the present study. Physical properties were determined by FTIR and thermal analysis. SEM results verified the fibril network structure of BC. The antibiofilm effect of BC was remarkable. This effect should be investigated in more detail, especially against various pathogens. In future studies, the antibiofilm effect of $\mathrm{BC}$ can be enhanced by modifying cellulose. Moreover, it has no cytotoxic effect. The moisture content, water retention capacity and swelling behavior of the isolated BC showed that it maintained the moisture environment constant, and it may be used for many medical applications. Further experiments will be required to test this hypothesis.

ACKNOWLEDGMENTS: The authors thank Pamukkale University Scientific Research Projects Coordinator (Project numbers 2017FEBE018 and 2018HZDP013) for financial support.

\section{REFERENCES}

1 H. Toyosaki, T. Naritomi, A. Seto, M. Matsuoka, T. Tsuchida et al., Biosci. Biotech. Biochem., 59, 1498 (1995), https://doi.org/10.1271/bbb.59.1498

2 V. T. Nguyen, B. Flanagan, M. J. Gidley and G. A. Dykes, Curr. Microbiol., 57, 449 (2008), https://doi.org/10.1007/s00284-008-9228-3

3 A. G. Matthysse, J. Bacteriol., 154, 906 (1983), https://jb.asm.org/content/154/2/906.short

4 D. R. Nobles, D. K. Romanovicz and R. M. Brown Jr., Plant Physiol., 127, $529 \quad$ (2001), https://doi.org/10.1104/pp.010557

5 C. Napoli, F. Dazzo and D. Hubbell, Appl. Microbiol., $\quad 30, \quad 123 \quad$ (1975), https://aem.asm.org/content/30/1/123.short

6 C. Solano, B. García, J. Valle, C. Berasain, J. M. Ghigo et al., Mol. Microbiol., 43, 793 (2002), https://doi.org/10.1046/j.1365-2958.2002.02802.x

7 A. H. Basta and H. El-Saied, J. Appl. Microbiol., 107, 2098 (2009), https://doi.org/10.1111/j.13652672.2009.04467.x

8 Y. Z. Wan, H. Luo, F. He, H. Liang, Y. Huang et al., Compos. Sci. Technol., 69, 1212 (2009), https://doi.org/10.1016/j.compscitech.2009.02.024

9 D. Ciechańska, Fibres Text. East. Eur., 12, 69 (2004), http://www.fibtex.lodz.pl/48_18_69.pdf
10 S. Zang, R. Zhang, H. Chen, Y. Lu, J. Zhou et al., Mater. Sci. Eng. C, 46, $111 \quad$ (2015), https://doi.org/10.1016/j.msec.2014.10.023

11 L. Rozenberga, M. Skute, L. Belkova, I. Sable, L. Vikele et al., Carbohyd. Polym., 144, 33 (2016), https://doi.org/10.1016/j.carbpol.2016.02.025

12 A. Svensson, E. Nicklasson, T. Harraha, B. Panilaitisa, D. L. Kaplan et al., Biomaterials, 26, 419 (2005), https://doi.org/10.1016/j.biomaterials.2004.02.049

13 F. Mohammadkazemi, M. Azin and A. Ashori, Carbohyd. Polym., 117, $518 \quad$ (2015), https://doi.org/10.1016/j.carbpol.2014.10.008

14 F. Cakar, A. Kat1, I. Özer, D. D. Demirbag, F. Sahin et al., Biochem. Eng. J., 92, 35 (2014), https://doi.org/10.1016/j.bej.2014.07.002

${ }_{15}$ S. Bae, Y. Sugano and M. Shoda, J. Biosci. Bioeng., 97, 33 (2004), https://doi.org/10.1016/S13891723(04)70162-0

16 C. Castro, I. Cleenwerck, J. Trcek, R. Zuluaga, P. De Vos et al., Int. J. Syst. Evol. Microbiol., 63, 1119 (2013), https://doi.org/10.1099/ijs.0.043414-0

17 P. Carreira, J. A. S. Mendes, E. Trovatti, L. S. Serafim, C. S. R. Freire et al., Bioresour. Technol., 102, 7354

(2011),

https://doi.org/10.1016/j.biortech.2011.04.081

18 S. Hestrin and M. Schramm, Biochem. J., 58, 345 (1954), https://doi.org/10.1042/bj0580345

19 K. C. Fugelsang and C. G. Edwards, "Wine Microbiology Practical Applications and Procedures", Springer, US, 2007, https://doi.org/10.1007/978-0-38733349-6

20 B. E. Rangaswamy, K. P. Vanitha and B. S. Hungund, Int. J. Polym. Sci., 2015, 8 (2015), https://doi.org/10.1155/2015/280784

21 A. B. McKenna, D. Mikkelsen, W. J. Bernhard, M. J. Gidley and N. W. Menzies, Cellulose, 16, 1047 (2009), https://doi.org/10.1007/s10570-009-9340-y

22 W. C. Lin, C. C. Lien, H. J. Yeh, C. M. Yu and S. H. Hsu, Carbohyd. Polym., 94, 603 (2013), https://doi.org/10.1016/j.carbpol.2013.01.076

23 A. Jain and A. Agarwal, J. Microb. Meth., 76, 88 (2009), https://doi.org/10.1016/j.mimet.2008.09.017

24 U. A. Sezer, V. Sanko, Z. N. Yuksekdag, D. Uzundağ and S. Sezer, Cellulose, 23, 3209 (2016), https://doi.org/10.1007/s10570-016-1000-4

25 J. Wang, J. Tavakoli and Y. Tang, Carbohyd. $\begin{array}{llll}\text { Polym., } & \text { 219, } & 63 & \text { (2019), }\end{array}$ https://doi.org/10.1016/j.carbpol.2019.05.008

26 R. Jonas and L. F. Farah, Polym. Degrad. Stabil., 59, 101 (1998), https://doi.org/10.1016/S01413910(97)00197-3

27 A. Budhiono, B. Rosidi, H. Taher and M. Iguchi, Carbohyd. Polym., 40, $137 \quad$ (1999), https://doi.org/10.1016/S0144-8617(99)00050-8

28 G. F. Picheth, C. L. Pirich, M. R. Sierakowski, M. A. Woehl, C. N. Sakakibara et al., Int. J. Biol. Macromol., $\quad$ 104, $97 \quad$ (2017), https://doi.org/10.1016/j.ijbiomac.2017.05.171 
29 P. Bayazidi, H. Almasi and A. K. Asl, Int. J. Biol. Macromol., $\quad \mathbf{1 0 7}, \quad 2544 \quad$ (2018), https://doi.org/10.1016/j.ijbiomac.2017.10.137

30 S. Adepu and M. Khandelwal, J. Mater. Sci., 53, 1596 (2018), https://doi.org/10.1007/s10853-0171638-9

31 G. Krasowski, R. Wicher-Dudek, J. Paleczny, I. Bil-Lula, K. Fijałkowski et al., Appl. Sci., 9, 5321 (2019), https://doi.org/10.3390/app9245321

32 Z. Y. Zhang, Y. Sun, Y. D. Zheng, W. He, Y. Y. Yang et al., Mater. Sci. Eng. C, 106, 110249 (2020), https://doi.org/10.1016/j.msec.2019.110249

33 S. Moreira, N. B. Silva, J. Almeida-Lima, H. A. O. Rocha, S. R. B. Medeiros et al., Toxicol. Lett., 189, 235 (2009),

https://doi.org/10.1016/j.toxlet.2009.06.849

34 S. Guo and L. A. Dipietro, J. Dent. Res., 89, 219 (2010), https://doi.org/10.1177/0022034509359125

35 G. Han and R. Ceilley, Adv. Ther., 34, 599 (2017), https://doi.org/10.1007/s12325-017-0478-y

36 R. Naomi, R. Idrus and M. B. Fauzi, Int. J. Environ. Res. Public Health, 17, 6803 (2020), https://doi.org/10.3390/ijerph17186803

37 R. Portela, C. R. Leal, P. L. Almeida and R. G. Sobral, Microb. Biotechnol., 12, 586 (2019), https://doi.org/10.1111/1751-7915.13392

38 M. Ul-Islam, J. H. Ha, T. Khan and J. K. Park, Carbohyd. Polym., 92, $360 \quad$ (2013), https://doi.org/10.1016/j.carbpol.2012.09.060

39 M. W. Ullah, M. Ul-Islam, S. Khan, Y. Kim, J. H. Jang et al., RSC Adv., 6, 22424 (2016), https://doi.org/10.1039/C5RA26704H

40 M. Ul-Islam, M. W. Ullah, S. Khan and J. K. Park, Korean J. Chem. Eng., 37, 925 (2020), https://doi.org/10.1007/s11814-020-0524-3

${ }^{41}$ S. Gea, C. T. Reynolds, N. Roohpour, B. Wiriosentono, N. Soykeabkaew et al., Bioresour. Technol., $\quad \mathbf{1 0 2}, \quad 9105 \quad$ (2011), https://doi.org/10.1016/j.biortech.2011.04.077

42 S. A. de Oliveira, B. C. da Silva, I. C. RiegelVidotti, A. Urbano, P. C. de Sousa et al., Int. J. Biol. Macromol., $\quad 97, \quad 642 \quad$ (2017), https://doi.org/10.1016/j.ijbiomac.2017.01.077
43 J. George, K. V. Ramana and A. S. Bawa Siddaramaiah, Int. J. Biol. Macromol., 48, 50 (2011), https://doi.org/10.1016/j.ijbiomac.2010.09.013

44 P. C. S. Faria-Tischer, C. A. R. Costa, I. Tozetti, L. H. Dall'Antonia and M. Vidotti, RSC Adv., 6, 9571 (2016), https://doi.org/10.1039/C5RA25332B

45 A. Vazquez, M. L. Foresti, P. Cerrutti and M. Galvagno, J. Polym. Environ., 21, 545 (2013), https://doi.org/10.1007/s10924-012-0541-3

${ }^{46}$ H. S. Barud, C. A. Ribeiro, M. S. Crespi, M. A. U. Martines, J. Dexpert-Ghys et al., J. Therm. Anal. Calorim., $\quad 87, \quad 815 \quad$ (2007), https://doi.org/10.1007/s10973-006-8170-5

47 D. Klemm, "Comprehensive Cellulose Chemistry: Fundamentals and Analytical Methods", Wiley-VCH, 1998,

https://www.cabdirect.org/cabdirect/abstract/20000609 594

48 N. Halib, M. C. I. M. Amin and I. Ahmad, Sains Malays., 41, 205 (2012)

49 B. Surma-Ślusarska, S. Presler and D. Danielewicz, Fibres Text. East. Eur., 16, 108 (2008)

50 J. X. Sun, F. Xu, X. F. Sun, B. Xiao and C. Sun, Polym. Degrad. Stabil., 88, $521 \quad$ (2005), https://doi.org/10.1016/j.polymdegradstab.2004.12.013

51 R. Bottom, in "Principles and Applications of Thermal Analysis", edited by P. Gabbott, Blackwell Publishing, UK, 2008, Chapter 3, https://doi.org/10.1002/9780470697702

52 H. I. Jung, O. M. Lee, J. H. Jeong, Y. D. Jeon, K. H. Park et al., Appl. Biochem. Biotechnol., 162, 486 (2010), https://doi.org/10.1007/s12010-009-8759-9

53 G. Gayathry and G. Gopalaswamy, Indian J. Fibre Text. Res., 39, 93 (2014), http://nopr.niscair.res.in/handle/123456789/27372 